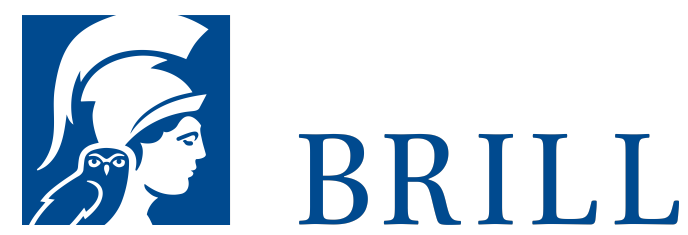

\title{
Zeitungslektüre im "Mann ohne Eigenschaften"
}

\section{Author: Hermann Bernauer}

ie Zeitung wird im Mann ohne Eigenschaften vielfach und in intrikat vermittelter Weise gele-sen. Von der Musilkritik jedoch ist sie bisher kaum beachtet wor-den. Diese Studie fragt nach ihrer Funktion im intertextuellen Spiel. Sie erwächst ihr, wie Bernauers Lektüre zeigt, aus dem Gegen-satz zur literarischen Tradition, zumal der Klassikrezeption des 19. Jahrhunderts - von der sich der MoE absetzt, indem er sich den Aktualitätsanspruch der Zeitung zu eigen macht. Doch tut er dies nur im Vorübergehen (und ist deshalb auch kein Ro-man der Neuen Sachlichkeit). Im Unterschied zur Zeitung, die bloß als aktuell herausstellt, was be-reits eingetroffen ist, optiert der MoE für einen emphatischen Begriff von Aktualität, der die Literatur, als kreatives Potential, wiederum ins Spiel bringt. Hermann Bernauer hat deutsche, englische und französische Literatur stu-diert. Er lebt in Genua und ist in der Erwachsenenbildung tätig.

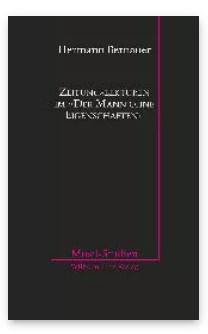

Pages: 170

Seiten

Language:

German

Subjects:

German,

Literature and

Cultural Studies

Publisher: Brill |

Fink

Series:

Musil-Studien,

Volume: 36

E-Book (PDF)

Released online: o2 Sep 2019

ISBN: $978-3-$

8467-4456-7

List price

USD $\$ 52.00$

Paperback

Publication date:

$25 \mathrm{Jul} 2007$

ISBN: 978-3-

7705-4456-1

List price

USD $\$ 52.00$ 
For more information see brill.com

Order information: Order online at brill.com +44330 333 0049 | customerservices@brill.com Submission information: brill.com/authors

Titles published by Brill | Fink, Brill | mentis or Brill | Schöningh: +49(o)715413279216| brill@brocom.de 